\title{
IDENTIFICATION OF ENVIRONMENTAL HEALTH AND SAFETY IN FACTORY OF HOSPITAL BEDS AT. X BEKASI
}

\author{
Dwi Septian Wijaya ${ }^{a^{*}} ;$ Wilda Maulida $^{\mathrm{b}}$; \\ ${ }^{a, b}$ Department of Public Health ; University of Muhammadiyah Prof. DR. HAMKA \\ Jakarta 12130 ; Indonesia
}

\begin{abstract}
In this globalization era, especially in the face of international trade competition then the principle of the application of health and safety are the main requirements that will greatly affect the investment value, quality, and quantity of products, the company's sustainability and competitiveness of a country. The purpose survey is to identify health and safety hazards which include chemical, physical, biological, ergonomic, and psychological hospital bed factory in PT. X Bekasi. The method used to survey and interview in the work unit welding, painting, assembling, and factory environments. Based on the survey results of the use of personal protective equipment (PPE) is pretty good and secure, while at 4 locations are all well qualified for occupational safety, health, and environment.
\end{abstract}

Keywords: survey ; hazard and risk identification ; occupational safety and health ; personal protective equipment

\section{Introduction}

Health and Safety is the key to the creation of decent working conditions and strong preventive safety culture. Occupational risks that are often experienced labor force includes occupational accidents and occupational diseases. The difference between the two types of risk as a result of this work lies in the time it happened. Work accident is an event that usually occurs suddenly and violence against the physical structure or the human body. Like hit a hard object, cut off sharp objects, falls from height and more.

While the risk of occupational disease arising out slowly and can take 10 years to 20 years (Suryati, 2015). But from the standpoint of social security programs, both the risks of this work have the same result, which can lead to disability, death, and treatment. Other than that, the amount of compensation for the risks associated with such work is also quite similar. Accident is an accident that occurred in connection with employment relationship,

*) Corresponding Author (Dwi Septian Wijaya)

Email: dwiseptianw@gmail.com including illnesses arising from employment relationship.

Implementation of occupational health, and safety activities are carried out should meet the standards of developed countries. Especially countries which are the representations of the international community on the requirements of a product or service, including good quality, safe to use, environmentally friendly, and meet certain international standards such as ISO 9001 series, ISO 14000 series, OHSAS 18000 series.

The purpose of health and safety is to protect the safety of workers in order to achieve optimal productivity. Occupational health and safety efforts to guarantee the safety and improve the health of workers by preventing accidents and occupational diseases, control of hazards in the workplace, health promotion, treatment, and rehabilitation. Four things that cause high rates of work accidents is the application of occupational safety and health in the company and the community is still low, the application of the examination test occupational health and safety is also low, the quality and quantity inspectors both inspectors and health and safety inspectors low employment and the 
duties and functions inspectors since regional autonomy was not optimal, especially in monitoring the health and safety program (Suryatri, 2015).

Control of hazards in the workplace, health promotion, treatment, and rehabilitation. Four things that cause high rates of work accidents is the application of occupational safety and health in the company and the community is still low, the application of the examination test occupational health and safety is also low, the quality and quantity inspectors both inspectors and health and safety inspectors low employment and the duties and functions inspectors since regional autonomy was not optimal, especially in monitoring the health and safety program (Suryatri, 2015).

Control of hazards in the workplace, health promotion, treatment, and rehabilitation. Four things that cause high rates of work accidents is the application of occupational safety and health in the company and the community is still low, the application of the examination test occupational health and safety is also low, the quality and quantity inspectors both inspectors and health and safety inspectors low employment and the duties and functions inspectors since regional autonomy was not optimal, especially in monitoring the health and safety program (Suryatri, 2015).

To find out their knowledge of health and safety, working conditions, especially knowing the manufacturing plant Hospital beds, knowing the use of PPE in the workplace, knowing the control and prevention of occupational accidents and know the health facilities that exist in the workplace.

\section{Method}

\section{a. Type of activity}

This activity is done by observation workplaces and workers in a hospital bed industry by identifying the material, equipment or processes that work well potentially dangerous chemical, biological, physical, ergonomic, and psychological.

\section{b. Activity Points}

Points implementation of this survey was conducted in PT X Bekasi. The timing of activity Date May 3, 2018.

\section{c. Data Acquisition Techniques}

Data acquisition techniques that do that is by interview and observation method. Methods interviews were conducted with workers in the workplace about the daily work in the area, followed by a method of direct observation in the workplace on the dangers of hazard that may arise, either from equipment, work attitude, work environment and work processes. It also conducted a study of the documentation that is taking pictures of objects and subjects that support the observations made.

\section{d. Observation methods}

Observation methods. Broadly, the observation means any activity to take measurements. The observations were made to observe the workers, the working environment, machinery and tools used during the manufacturing process of hospital beds. The instrument used is a sheet Walk Through Survey (WTS). The interview method, data retrieval is done through conversation or question and answer between researcher and respondent (workers). The instrument used to assist the interview process.

\section{Result and Discussion}

\section{a. Occupational Health Services at PT. X}

It has become the company's policy that each employee get a safe and healthy place to carry out everyday tasks. In principle, all parties should seek and take positive steps so that all employees are guaranteed and safe and healthy working. Occupational Health Services conducted a comprehensive approach that includes the service of preventive, promotive, and curative.

\section{b. Preventive services}

This service is provided in order to prevent the occurrence of occupational diseases, infectious diseases in the working environment by creating conditions for workers and machines or workplace to enable ergonomic, physical condition or maintain an adequate work environment and does not cause pain or harm to workers, and to maintain healthy. Among other activities, namely:

1. Medical examination

2. Healthy Work Environment

3. Self-protection against the dangers of the job

4. Adjustment of man and machine and work tool

5. Environmental hazard control work to 
be in a safe condition (recognition, measurement, and evaluation)

6. Installation instructions for using PPE when it goes into the factory as well as in every tool should use PPE

7. APAR availability of 50,30 and Sprinkler Hydrant as much as 1

8. Flagging a green lane for visitors or employees who walk in the area of the plant.

\section{c. Promotive services}

Improved health (promotion) to the worker intended for workers' physical and mental state is always in good condition. This service is provided with the aim of improving health, enhancing efficiency and labor productivity in the workplace. Its activities include the following:

1. Education and health information work

2. Maintenance and improvement of conditions of a healthy work environment

3. Improved health status (disease-free) in general

4. Improving the nutritional status

5. Psychological counseling

\section{d. Curative services}

Medical services to workers who suffer occupational specific medication or treatment related to his work in general and treatment efforts to prevent the spread of infectious diseases in the work environment. This service is provided to workers who have shown health problems or symptoms by treating the disease early in order to quickly heal and prevent complications or transmission of his family or his friends. Its activities include the following: (Treatment of common diseases and treatment of the disease and occupational accidents).

In the implementation of this curative services PT. X cooperate with private clinics are located in the surrounding area. Labor in PT. $X$ also get good health insurance coverage BPJS health and commercial insurance that can be used when sick.

e. Application of Occupational Health in PT. X 1) Chemical Hazards

Chemicals are used for various purposes in the workplace. The chemicals can be either a final product or part of raw materials used to manufacture a product. It can also be used as lubricants, cleaners, fuels for energy side or by products. In the production process in PT. $X$ chemicals used are in the process of welding and painting. The chemical used is liquid thinners and chlorinated solvents. In the use of thinner fluids and chlorinated solvents have been awarded the labeling of "Flammable" on the packaging so it can provide awareness to employees during use.

\section{2) Physical Hazards}

Physical factors are factors in the workplace that is physics between alain noise, vibration, work climate. These factors may be certain parts resulting from the production process or unwanted side products.

\section{a) Noise}

Noise is unwanted sound all that comes from the production process tools or working tools which at a certain level can cause hearing loss. Loud noises, excessive or prolonged exposure may damage the sensitive nerve tissue in the ear, causing temporary or permanent hearing loss. It is often overlooked as a health problem, but it is one of the main physical hazard. Exposure to noise limits set a threshold value of $85 \mathrm{~dB}$ for 8 hours. In handling noise PT. X has made several efforts such as:

1. Identify the cause of the common sources of noise, such as machinery, ventilation systems and power tools.

2. Workplace inspections for noise exposure. Inspections have been carried out at the time housed sleep to ensure that all sources of noise have been well identified.

3. The use of personal protective equipment such as earplugs (earplug or earmuff) by employees in locations with high levels of noise that cannot be reduced.

\section{b) Lighting}

Lighting in each workplace should be qualified to do the job. Appropriate lighting is very important for improving the quality and productivity. When the lighting is less appropriate, 
employees were forced to stoop to try to focus their vision, so uncomfortable and can cause problems with the back and an eye on the long term and can slow their work. In handling the lighting PT. $X$ has made several efforts such as: (The location of each employee has had the lighting according to their work unit and position lights do not impede the movement of employees but still be able to meet the requirements).

c) Vibration

Vibration is the movement back and forth quickly. The movement occurs regularly from objects or media with alternating directions of his position. It clearly can negatively affect all or part of the body. Limitation of working tools contact vibration directly or indirectly on the arm and hand labor is set at $4 \mathrm{~m} / \mathrm{sec}^{2}$, In handling the vibration PT. $X$ has made several efforts such as:

1) Controlling vibration at source by the underlying hardware to install the vibration absorber or shock absorbers.

2) Replacing older equipment with new vibration-free models.

3) Providing appropriate personal protective equipment to employees who operate the machine vibrates, eg gloves that absorbs vibration (and ear protectors to the accompanying noise).

\section{d) Work climate}

When the temperature is above or below the normal range, this situation slows down the work. It is a natural and physiological responses and is one reason why it is very important to maintain the temperature and humidity level of comfort in the workplace. These factors can significantly affect the efficiency and productivity of individual employees. In order to function efficiently the human body needs to remain within the normal temperature range. It is necessary for the appropriate working environment for workers while doing the job. In handling the work climate PT. X has made several efforts such as:

1) The position of the walls and room dividers do not restrict air flow.

2) Adequate ventilation and good so that the air flow can blow directly on those who work near it.

3) Reducing the physical workload for those who work in hot conditions and make sure they have enough water and rest.

\section{f. Biological Hazards}

Biological factors of occupational diseases is very diverse kinds, such as water quality. Rather bedded by factors other causes of occupational diseases, biological factors can be transmitted from person workers to other workers. In handling this biological hazard PT. X has made several efforts such as:

1. Immunization for the prevention of diseases that can be caused by viruses or bacteria.

2. Making the great and good ventilation for handling the flow of air.

\section{g. Ergonomic Hazards}

Preparation of the workplace and the appropriate seating should be arranged such that no harmful effects on health. Places to sit pretty and shall be provided for workers and workers should be given ample opportunity to use it.

Effective ergonomic design provides workstation, equipment and supplies convenient and efficient for workers to use. It also creates a healthy working environment, for organizing the work process to control or eliminate potential dangers. The risk potential ergonomic hazards will increase with the monotony of repetitive tasks, awkward postures, and lack of rest. In handling the ergonomic PT. X has made several efforts such as: (Provide a working position or sitting workstation Designing appropriate and so the equipment is 
easily accessible and relaxed shoulders in a neutral position and your arms straight forward when it works).

\section{h. Psychological Dangers}

Job stress is a result of the state of the workplace, organizational involvement and support tasks, workload, excessive working hours, work responsibilities. Shift work is one stressor that can cause health problems directly or indirectly. Jobs can give satisfaction and a challenge, otherwise can also be a nuisance and a threat. Factors that could cause health problems caused by work that is tired and workload. Increasingly heavy workload if the labor is also required to work with the rhythm of the work faster and higher production targets. In handling the psychological harm PT. $X$ has made several efforts such as:

a. Set the rest each day for 3 times (10:00 to $10: 15 ; 12: 15$ to $13: 00 ; 15: 30$ to $15: 45)$.

b. The setting unit divided by the educational background of each employee.

The whole idea or innovation given by each employee will provide input and rewarded.

\section{Conclusion and Suggestion}

Occupational health learn about health in relation to work and the working environment. Its reach is initially limited to a disease or an accident caused by the work itself, the conditions of work or the working environment. In more detail it can be said that essentially the occupational health study all the factors related to the work, methods of work, working conditions and working environment that may cause occupational illness, accident or other health problems, such as the danger of chemical and physical properties, such as exposure of dust, vapors or gases are inhaled, noise induced deafness, silicosis due to inhalation and accumulation of dust-free silica ( $\mathrm{SiO} 2)$ in the lungs, fatigue due to working too long and others.

Every employee has been equipped with the knowledge 5S, hourensou, 3G as a working basis given the Japanese culture through internal and external training. For employees at the production so come with external and internal training in accordance with their respective sections.
With the motto "As Human for Human" and the spirit of hard work, PT. X will always strive to provide perfect service for customers. PT. X always pay attention to after-sales service for all customers. Although it has been over one year of the warranty period is given from the delivery of goods, PT. X always pay attention to selling services by directly contacting hospitals across Indonesia at least 1 times a year.

The use of protective equipment in the workplace, especially in the manufacturing of Hospital beds, fairly good and safe, well done by every employee, starting from production process welding processes, painting process, process assembly, until the area around the plant are all eligible either for safety or occupational health and environmental health workers. Occupational health services in PT. X has become the company's policy that each employee get a safe and healthy place to carry out everyday tasks. In principle, all parties should seek and take positive steps so that all employees are guaranteed and safe and healthy working.

Occupational Health Services conducted a comprehensive approach that includes the service of preventive, promotive, and curative until the area around the plant are all eligible either for safety or occupational health and environmental health workers. Occupational health services in PT. $X$ has become the company's policy that each employee get a safe and healthy place to carry out everyday tasks. In principle, all parties should seek and take positive steps so that all employees are guaranteed and safe and healthy working.

In principle, all parties should seek and take positive steps so that all employees are guaranteed and safe and healthy working. Occupational Health Services conducted a comprehensive approach that includes the service of preventive, promotive, and curative.

Occupational Health and Safety is the key to the creation of decent working conditions and a strong preventive safety culture. Based on the results of a study of environmental health and safety in hospital bed factory in PT. X. Bekasi, that the safety of work safety is very good.

\section{Acknowledgements}

I would like to show our gratitude to Poltekkes Kemenkes Semarang who has published the manuscript also thank for some parties who have helped this research. 


\section{References}

Arif Sumantri. 2010. The third edition of Environmental Health. Jakarta. 2010.

ILO (International Labor Organization), 2005. Practical Guidelines for Occupational Safety and Health in Construction Sector, Jakarta: ILO, Ministry of Manpower and Transmigration Republic of Indonesia and the Safety and Health Council National Labor force.
Regulation of the Minister of Labor of the Republic of Indonesia Number: PER.05 / MEN / 1996, K3 Management System in a company.

Ramli, S. 2010. Management System Occupational Health and Safety, OHSAS 18001, Publisher Dian Rakyat, Jakarta.

Suryatri D. 2015. Principles - principles of Occupational Health and Safety, and the Environment. Malang: Mountains Ocean. 